\title{
Effects of Beet necrotic yellow vein virus in Spinach Cultivars
}

\author{
B. Mou, K. Richardson, S. Benzen, and H.-Y. Liu, United States Department of Agriculture (USDA), Agricultural Research Service, \\ 1636 East Alisal Street, Salinas, CA 93905
}

\begin{abstract}
Mou, B., Richardson, K., Benzen, S., and Liu, H.-Y. 2012. Effects of Beet necrotic yellow vein virus in spinach cultivars. Plant Dis. 96:618-622.

Beet necrotic yellow vein virus (BNYVV) causes one of the most economically destructive diseases of sugar beet (Beta vulgaris), rhizomania, which may reduce sugar yield by $80 \%$. This field investigation was conducted to evaluate the interactions between spinach genotypes and different BNYVV strains, and to determine whether BNYVV is transmitted through spinach seeds. Eight commercial spinach cultivars were planted in two BNYVV-infested fields and two control fields in Salinas, CA in 2009. Spinach plants in the BNYVV-infested fields showed disease symptoms of yellow-green or light-green vein clearing, mottling, or yellow-green chlorotic lesions on younger leaves as early as 28 days after planting (four- to six-true leaf stage). Leaves may also

lateral roots and leaf number but a decrease in leaf weight compared to healthy plants. Infected plants often became stunted, deformed, wilted, and dead. Symptomatic leaves and roots from plants with or without leaf symptoms in BNYVV-infested fields all tested positive for BNYVV by enzyme-linked immunosorbent assay. A more aggressive (resistance-breaking) strain of BNYVV led to higher disease incidence in spinach than in the wild type. BNYVV was not transmitted through spinach seeds. There were significant differences in disease development among cultivars, with disease incidence ranging from 8 to $44 \%$, suggesting that genetic improvement of BNYVV resistance through spinach breeding should be feasible.
\end{abstract} become stiff, more crinkled, and necrotic. There was an increase of
Beet necrotic yellow vein virus (BNYVV) causes rhizomania, one of the most economically important diseases of sugar beet (Beta vulgaris L.) worldwide, resulting in major reductions in root yield and sugar content. The disease was so named because affected sugar beet plants have a proliferation of lateral roots on the main taproots. BNYVV has rod-shaped particles containing four or five single-stranded RNAs and is transmitted by the soilborne plasmodiophorid, Polymyxa betae Keskin (9). The disease was first reported in Italy in the 1950s (6). It has since been found in many sugar beet growing regions in Asia, the United States, and southern and central European countries $(2,27)$. In the United States, the disease was first identified in California in 1984 (8), but now it has spread to all major sugar beet production regions in the country (21).

At present, planting sugar beet cultivars with partial resistance is the only economical means to control rhizomania disease. The first resistance gene, $R z 1$, was isolated from sugar beet germplasm in California (16). Two additional resistant genes, $R_{z} 2(23,24)$ and $R z 3$ (15), were derived from wild beet, and they are linked to $R z 1$ on chromosome III (10). Plants with one or two resistant genes in a heterozygous condition have lower titer of BNYVV than susceptible cultivars (19).

In 2002-2003, severe symptoms of rhizomania were observed in several sugar beet fields planted with a cultivar carrying the $R z 1$ resistant gene in the Imperial Valley of California. Certain isolates of BNYVV had overcome the resistant gene (19). Since 2003, the resistance-breaking BNYVV (RB-BNYVV) strains have appeared in other sugar beet-growing states of the United States, including Colorado, Idaho, Minnesota, Nebraska, and Oregon (17).

Like sugar beet, spinach also belongs to the family of Chenopodiaceae. Artificial inoculation experiments established spinach

Corresponding author: B. Mou, E-mail: beiquan.mou@ars.usda.gov

USDA is an equal opportunity provider and employer.

Accepted for publication 23 November 2011.

http://dx.doi.org/10.1094/PDIS-09-11-0748

This article is in the public domain and not copyrightable. It may be freely reprinted with customary crediting of the source. The American Phytopathological Society, 2012. as one of the hosts of BNYVV $(11,19,22)$. In 1995, BNYVV was identified to naturally infect spinach crops in Italy (3). We reported occurrence of BNYVV in spinach crops in California in 2010 (18). However, BNYVV-caused disease development in spinach fields has not been studied, and there is no information regarding the response of different spinach cultivars to BNYVV. This field investigation was conducted to evaluate the interactions between spinach genotypes and different BNYVV strains, and to determine whether BNYVV is transmitted through spinach seeds.

\section{Materials and Methods}

Cultivars and field experiments. Eight spinach hybrid cultivars, 'Bolero', 'Bossanova', 'Cypress', 'Eagle', 'PV0063 (Lazio)', 'Nordic IV', 'Polar Bear', and 'Unipack 277', were planted in a field infested with the wild type of BNYVV at the Spence Farm of the Agricultural Research Station of the USDA, Salinas, CA on 5 May 2009. The same cultivars were also planted in a field with RB-BNYVV at the Hartnell College, Salinas, CA on 14 May 2009. These fields were inoculated with BNYVV in previous years to test sugar beet genotypes for resistance to rhizomania. The experimental design was a randomized complete block with four replications. Each plot consisted of a single row $2.4 \mathrm{~m}$ long with $3.4 \mathrm{~cm}$ between plants and $0.8 \mathrm{~m}$ between rows. As controls, the eight cultivars were also grown in two fields free of BNYVV at Spence Farm and Hartnell College in Salinas with the same experimental design.

After seedling emergence, the plots were observed every 2 to 3 days for the number of plants with disease symptoms. Seven weeks after planting, five plants with symptoms and five plants without symptoms were randomly selected and harvested from each plot in BNYVV-infected fields, and number of leaves with petiole per plant, plant weight (with roots), and total leaf weight (without roots) were determined. Root weight $=$ plant weight - total leaf weight. Weight per leaf $=$ total leaf weight/number of leaves per plant. Leaf and root tissues were also tested for BNYVV by using enzyme-linked immunosorbent assay (ELISA). Seeds were harvested from two plants with symptoms and two plants without symptoms in each plot.

ELISA. Harvested plants were washed with tap water to remove soil from roots. Leaf or root tissue weighing $0.2 \mathrm{~g}$ was taken from each plant, placed in sample extraction bags with $2 \mathrm{ml}$ of extraction buffer (0.05 M phosphate-buffered saline, $\mathrm{pH} 7.2 ; 0.5 \%$ Tween 
20; and $0.4 \%$ dry milk powder), and homogenized with a handheld roller press (Agdia, Inc., Elkhart, IN). Ten randomly selected seeds from each harvested symptomatic or asymptomatic plant were ground in a 1.5-ml Eppendorf tube with 1.0 $\mathrm{ml}$ of extraction buffer. Expressed sap (100 $\mu \mathrm{l}$ per well) was added to duplicate wells of a microtiter plate. Each plate also contained sap from healthy spinach plants grown in greenhouse as control.

Double-antibody sandwich ELISA (7) was used to detect BNYVV. Purified immunoglobulin G (IgG, $1 \mu \mathrm{g} / \mathrm{ml})$ obtained from an antiserum to BNYVV was used to coat microtiter plates. Alkaline phosphatase-conjugated anti-BNYVV IgG dilution was 1/1,000. Absorbance at $405 \mathrm{~nm}$ was measured $1 \mathrm{~h}$ after the addition of substrate using a Bio-Tek EL312e microplate reader (Winooski, VT). ELISA values 3 times greater than the mean of healthy control were considered positive.

Data analysis. Analysis of variance (ANOVA) was performed to test the effects of spinach genotypes on disease incidence and their interactions with experiment locations (BNYVV strains) as well as the relative ELISA values for all experiments using the general linear model procedure of JMP v. 5 (SAS Institute, Cary, NC). Spinach genotypes and locations were considered fixed effects, and replications were considered random effects. For comparisons between genotypes, $t$ tests were conducted with an error rate of $P=$ 0.05 .

\section{Results and Discussion}

About 4 weeks after planting, disease symptoms started to appear on leaves of spinach plants in BNYVV-infested fields at the four- to six-true leaf stages. Leaf symptoms differed for the two different BNYVV strains. In the field with the wild type BNYVV, yellow-green vein clearing became visible on younger leaves, usually starting from the lower part of the leaf, then spreading to the entire leaf (Fig. 1). Some plants also displayed yellow-green mottling on young leaves. Plants in the field with RB-BNYVV showed

Table 1. Average optical density (OD) ratio of spinach leaves with and without leaf symptoms from a Beet necrotic yellow vein virus (BNYVV)infested field at Spence Farm in Salinas, CA over healthy control plants from a greenhouse by enzyme-linked immunosorbent assay

\begin{tabular}{lcc}
\hline & \multicolumn{2}{c}{ BNYVV OD/healthy control ${ }^{\mathbf{z}}$} \\
\cline { 2 - 3 } Cultivar & With symptom & Without symptom $^{\text {Bit }}$ \\
\hline Bossanova & $7.32 \mathrm{~A}$ & $1.01 \mathrm{C}$ \\
Cypress & $7.31 \mathrm{~A}$ & $1.08 \mathrm{C}$ \\
PV0063 (Lazio) & $7.00 \mathrm{AB}$ & $1.05 \mathrm{C}$ \\
Eagle & $6.28 \mathrm{AB}$ & $1.04 \mathrm{C}$ \\
Bolero & $6.26 \mathrm{AB}$ & $1.06 \mathrm{C}$ \\
Nordic IV & $5.66 \mathrm{AB}$ & $1.05 \mathrm{C}$ \\
Polar Bear & $5.01 \mathrm{~B}$ & $1.11 \mathrm{C}$ \\
Unipack 277 & $4.95 \mathrm{~B}$ & $1.07 \mathrm{C}$ \\
\hline
\end{tabular}

${ }^{\mathrm{z}}$ Means with same letters were not significantly different at $P=0.05$.

Table 2. Mean disease incidences of eight spinach cultivars grown in a field infested with the wild type Beet necrotic yellow vein virus (BNYVV) at the Spence Farm and in a field with the resistance-breaking strain of BNYVV at Hartnell College in Salinas, CA in summer 2009

\begin{tabular}{|c|c|c|}
\hline \multirow[b]{2}{*}{ Spinach cultivar } & \multicolumn{2}{|c|}{ Plants with leaf symptom \% } \\
\hline & Spence $^{\mathrm{z}}$ & Hartnell \\
\hline Polar Bear & $26.7 \mathrm{~A}$ & $43.7 \mathrm{~A}$ \\
\hline Bolero & $19.4 \mathrm{AB}$ & $28.1 \mathrm{~B}$ \\
\hline Eagle & $26.3 \mathrm{~A}$ & $27.8 \mathrm{~B}$ \\
\hline Nordic IV & $21.6 \mathrm{AB}$ & $27.0 \mathrm{~B}$ \\
\hline Bossanova & $19.0 \mathrm{AB}$ & $20.3 \mathrm{~B}$ \\
\hline PV0063 (Lazio) & $14.6 \mathrm{BC}$ & $19.4 \mathrm{BC}$ \\
\hline Cypress & $8.4 \mathrm{C}$ & $17.6 \mathrm{BC}$ \\
\hline Unipack 277 & $13.1 \mathrm{BC}$ & $8.1 \mathrm{C}$ \\
\hline
\end{tabular}

${ }^{\mathrm{z}}$ Means with same letters in a column were not significantly different at $P$ $=0.05$. light-green or pale-green interveinal chlorosis (Fig. 2). Regardless of BNYVV strains, infected plants may exhibit stiff and/or crinkled leaves, necrotic leaf spots, deformation, stunting, wilting, and/or death of plants (Fig. 3). Symptomatic leaves from the eight cultivars all showed high optical density (OD) readings in ELISA and thus were positive for BNYVV, whereas symptomless leaves had the same OD as the healthy control, indicating negative result for BNYVV (Table 1). These data suggest that the leaf symptoms were caused by BNYVV.

There were significant differences in the progress of the disease among eight spinach cultivars. For example, in the field with RBBNYVV, disease incidence increased quickly in 'Polar Bear', whereas the disease developed slowly in 'Unipack 277' (Fig. 4). Analysis of variance for disease incidence showed that there were significant genotype and location (pathogen strain) effect, but the genotype by location interaction was not significant. Disease incidences were generally higher at the Hartnell College location with RB-BNYVV (ranging from 8.1 to $43.7 \%$ ) than at Spence Farm with the wild type BNYVV (ranging from 8.4 to $26.7 \%$, Table 2). This suggests that RB-BNYVV from sugar beet causes more disease incidence than the wild type in spinach as well. Among the eight spinach cultivars, 'Unipack 277' and 'Cypress' were more tolerant to BNYVV, whereas 'Polar Bear' and 'Eagle' were more susceptible to the disease at both test locations (Table 2). Combined with the lack of genotype $\times$ location interaction, these results suggest that genetic variation in BNYVV tolerance/resistance exist in spinach germplasm and the variability is stable over different pathogen strains.

Spinach plants infected with BNYVV displayed leaf symptoms early and frequently, whereas BNYVV-infected sugar beet plants rarely show leaf symptoms (20). When symptoms appear on sugar beet leaves, they generally resemble what we observed for spinach (20). The virus tends to be restricted to inoculated leaves of spinach and sugar beet, and rarely becomes systemic in host plants (26). BNYVV transmission through spinach roots easily resulted in systemic infection in our study.

As in sugar beet, there was an increase of lateral roots on BNYVV-infected spinach plants (Fig. 5). Susceptible cultivars had more lateral roots than tolerant cultivars, and plants with leaf symptoms showed more secondary roots than plants without leaf symptoms. Therefore, the degree of root proliferation seems to be an indicator of the extent of BNYVV infection in spinach.

There was no significant difference in the ELISA OD of root tissue between plants with leaf symptoms and plants without leaf

Table 3. Average optical density (OD) ratio of spinach roots for susceptible 'Polar Bear' and tolerant 'Unipack 277' with and without leaf symptoms from Beet necrotic yellow vein virus (BNYVV)-infested fields over healthy control plants from a greenhouse by enzyme-linked immunosorbent assay

\begin{tabular}{lcc}
\hline & \multicolumn{2}{c}{ BNYVV OD/healthy control $^{\mathbf{z}}$} \\
\cline { 2 - 3 } Cultivar & With leaf symptom & No leaf symptom \\
\hline Polar Bear & $5.00 \mathrm{~A}$ & $4.99 \mathrm{~A}$ \\
Unipack 277 & $3.65 \mathrm{AB}$ & $3.15 \mathrm{~B}$ \\
\hline
\end{tabular}

${ }^{\mathrm{z}}$ Means with same letters were not significantly different at $P=0.05$.

Table 4. Traits of eight spinach cultivars in a field infested with the wild type of Beet necrotic yellow vein virus (BNYVV) at Spence Farm, Salinas, CA in summer 2009

\begin{tabular}{lcc}
\hline Traits & No symptom $^{\mathbf{z}}$ & With symptom \\
\hline Plant wt., g & $117.6 \mathrm{~A}$ & $107.4 \mathrm{~A}$ \\
Leaf number & $18.2 \mathrm{~B}$ & $24.0 \mathrm{~A}$ \\
Total leaf wt., g & $113.1 \mathrm{~A}$ & $103.6 \mathrm{~A}$ \\
Root wt., g & $4.56 \mathrm{~A}$ & $3.81 \mathrm{~A}$ \\
Wt./leaf & $6.29 \mathrm{~A}$ & $4.26 \mathrm{~B}$ \\
\hline
\end{tabular}

${ }^{\mathrm{z}}$ Means with same letters in a row were not significantly different at $P=$ 0.05 . 


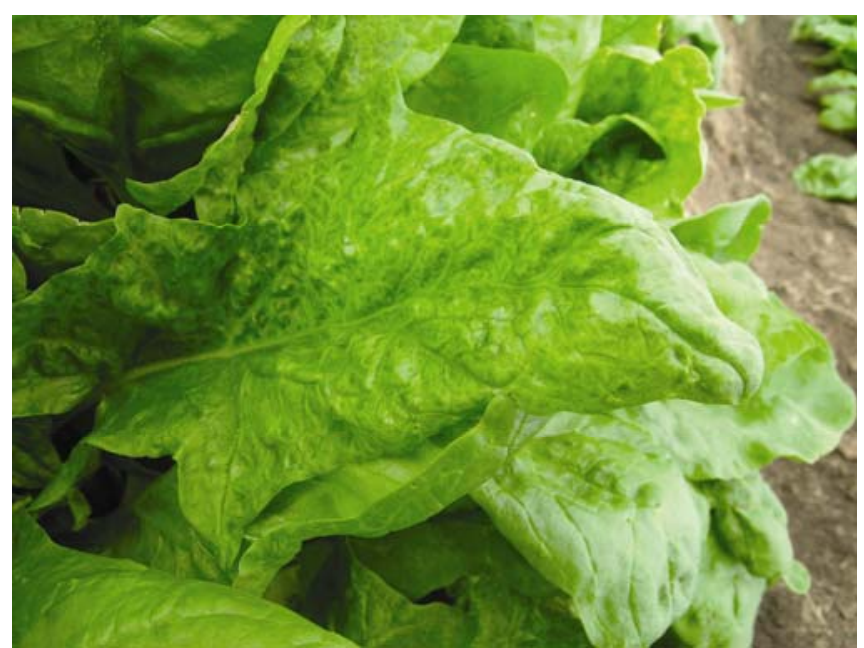

Fig. 1. Yellow-green vein-clearing symptom of spinach plants grown in a field infested with the wild type Beet necrotic yellow vein virus (BNYVV) at Spence Farm, Salinas, CA in summer 2009.

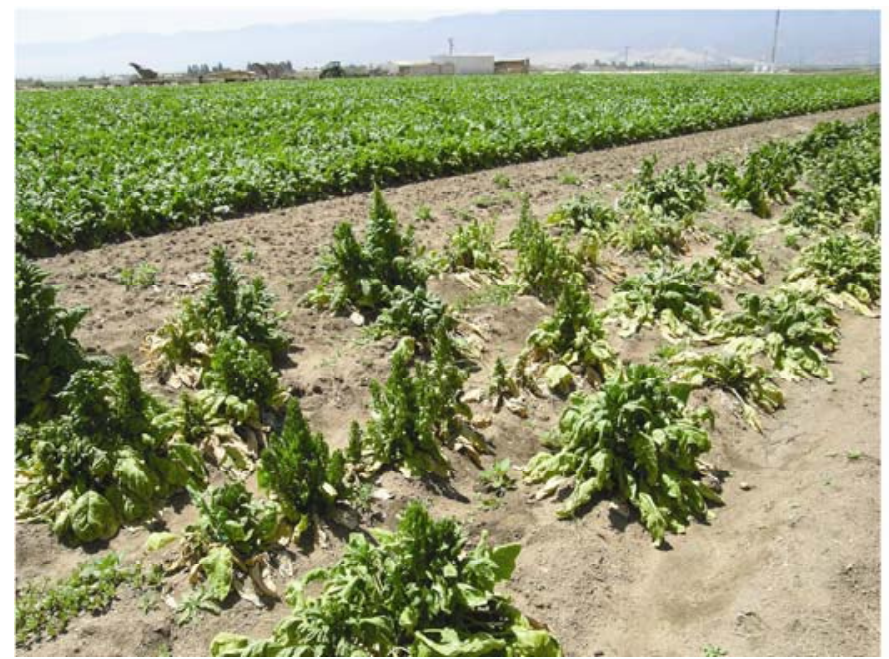

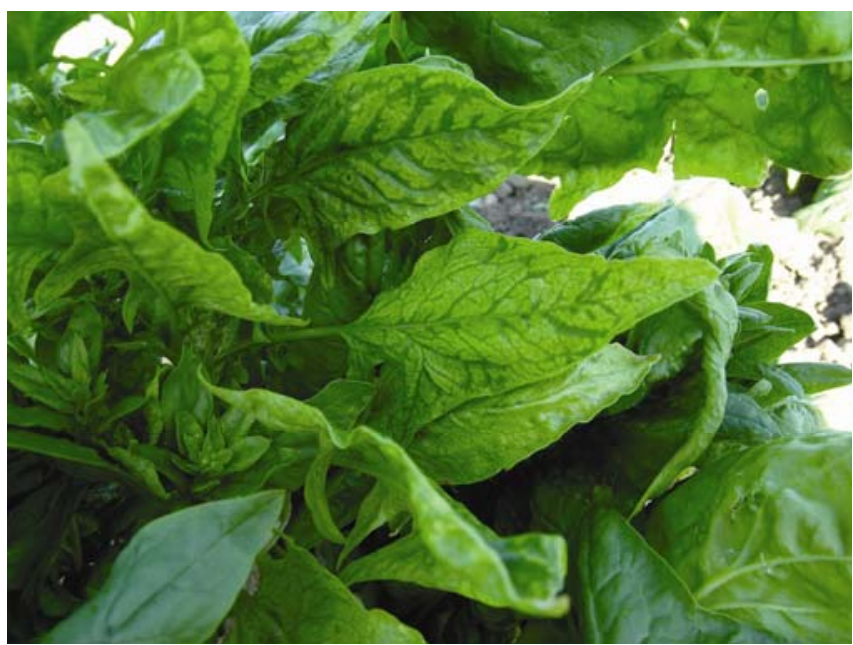

Fig. 2. Symptom of light-green or pale-green interveinal chlorosis on spinach plants in a field with the resistance-breaking strain of Beet necrotic yellow vein virus (BNYVV) at Hartnell College, Salinas, CA in summer 2009.

Fig. 3. Wilted or dead spinach plants in a field with the wild type Beet necrotic yellow vein virus (BNYVV) (left) as compared with the control plants in a field without BNYVV (right) at the same growth stages in Spence Farm, Salinas, CA in summer 2009.

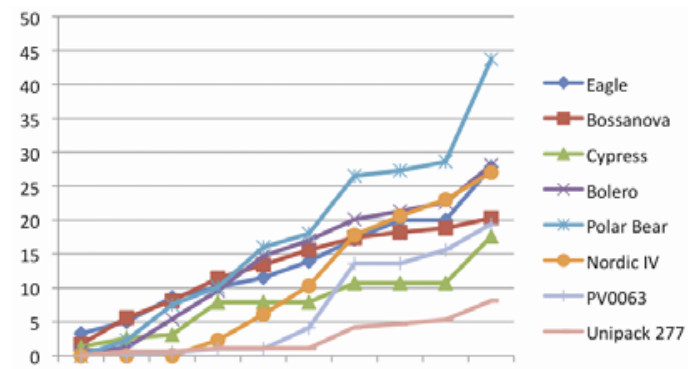

$6 / 116 / 126 / 146 / 16$ 6/18 6/20 6/23 6/25 6/28 7/10

Fig. 4. Progress of disease incidence (percent plants with leaf symptoms) for eight spinach cultivars in a field infested with the resistance-breaking strain of Beet necrotic yellow vein virus (BNYVV) at Hartnell College, Salinas, CA from 11 June to 10 July 2009.

symptoms from BNYVV-infested fields (Table 3). Therefore, the roots of a spinach plant can be infected even though no leaf symptoms are displayed. The roots of tolerant cultivar 'Unipack 277' had smaller OD, suggesting a lower titer of BNYVV than the roots of susceptible cultivar 'Polar Bear'. Rhizomania-resistant sugar beet plants have reduced accumulation of BNYVV in small rootlets, inhibition of the virus spread to the taproot, and a lack of rootlet proliferation and other symptoms $(13,25,28)$.

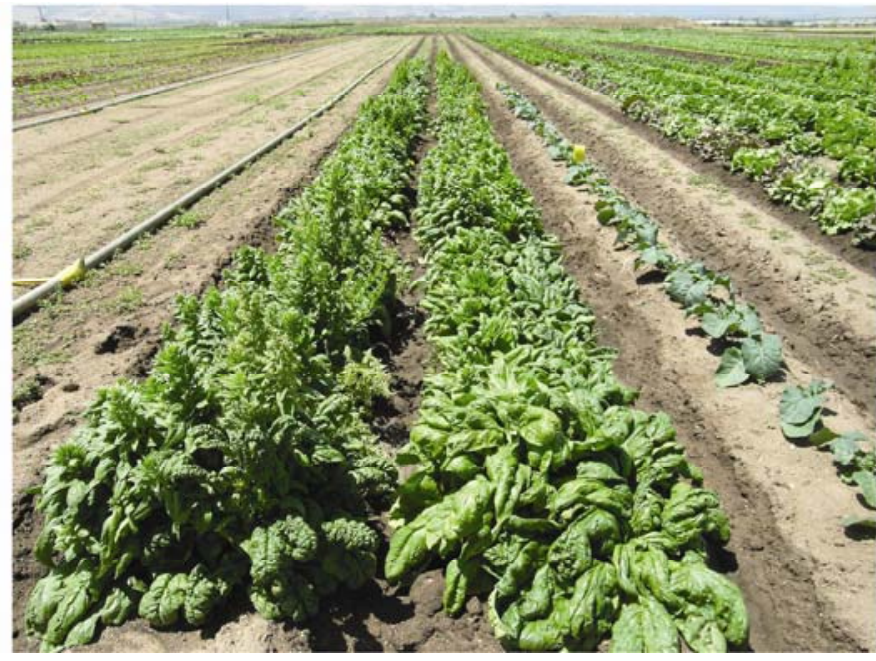

Data from the eight spinach cultivars showed that there was no significant difference in weights of total leaf, root, and plant between plants with and without leaf symptoms (Table 4). However, plants with leaf symptoms had more leaves and lower individual leaf weight. In spinach, BNYVV seemed to cause not only a proliferation of roots, but also of leaves.

Seeds harvested from plants of eight spinach cultivars with and without leaf symptoms in fields infested with the wild type and resistance-breaking strains of BNYVV all tested negative for BNYVV by ELISA (data not shown). This suggests that BNYVV is not transmitted through seeds. Direct transmission of BNYVV by sugar beet seeds could not be demonstrated either (12). In California, spinach grown for processed frozen, standard fresh market, and fresh market "baby leaf" (harvested at the four- to five-leaf stage) products is planted at 1.9 to $3.1,6.2$ to 9.1 , and 9.1 to 18.5 million viable seeds per hectare, respectively (14). If BNYVV were seed-transmitted in spinach, possible introduction or buildup of the virus in the soil would be a concern with such a high planting density.

In our experiments, the vein-clearing symptoms of BNYVV showed up on spinach leaves as early as 4 weeks after planting at four- to six-true leaf stage, which is about the time for commercial "baby leaf" spinach harvest. Diseased plants were found in a commercial spinach field in Ventura County of coastal California in 2009 and tested positive for RB-BNYVV (18). There was a proc- 


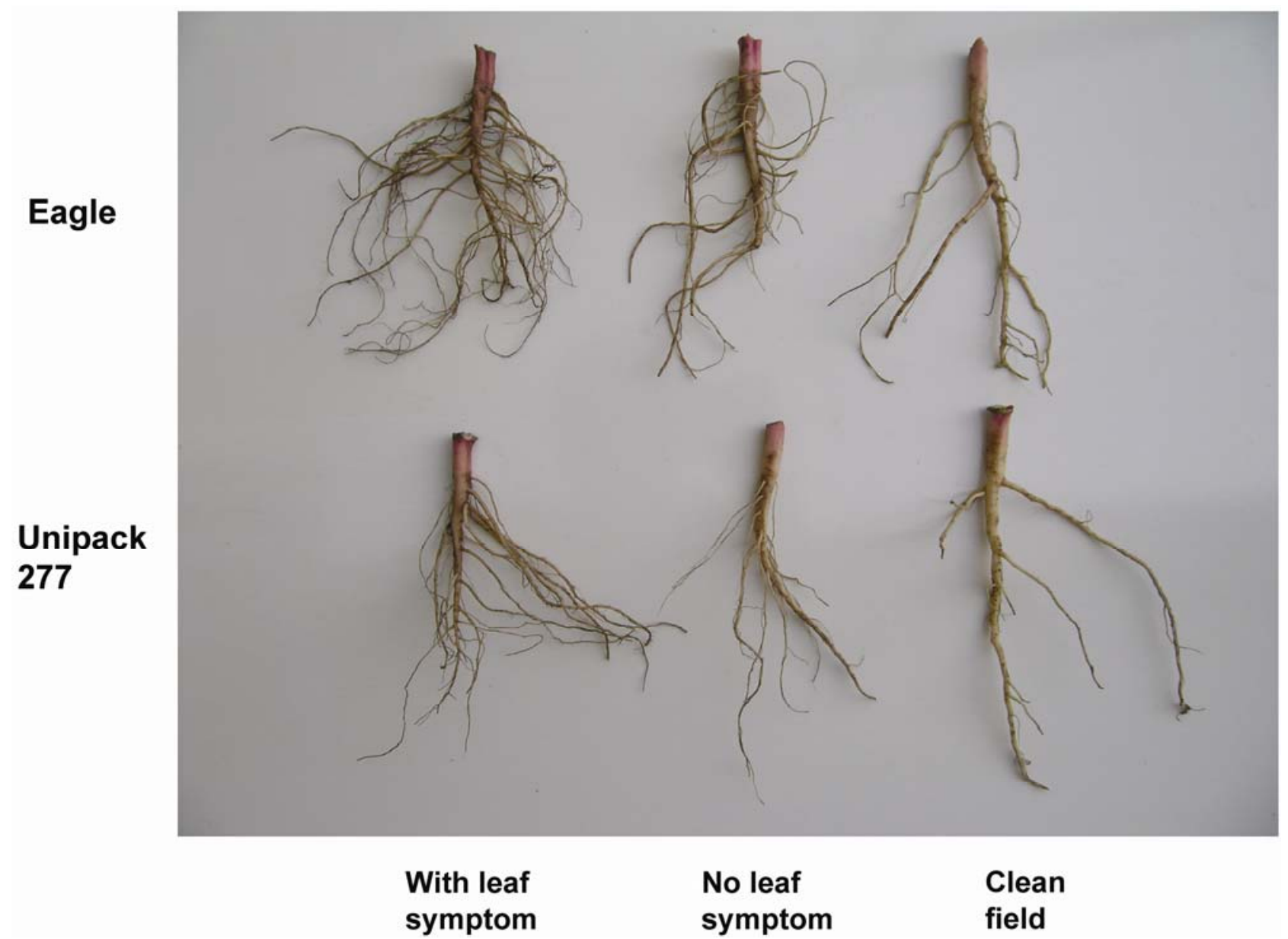

Fig. 5. Typical roots of Beet necrotic yellow vein virus (BNYVV)-susceptible spinach 'Eagle' and tolerant 'Unipack 277' with and without leaf symptoms from a field infested with the wild type BNYVV as well as roots of the two cultivars from a clean field (free of BNYVV).

essing plant in Ventura which processed sugar beet shipped from many production regions of California. It is possible those operations brought BNYVV into the area.

Sugar beet was grown in about 30 California counties including coastal, central, and southern valleys in the 1990s (5). California sugar beet acreage has steadily declined in the past decade, as production shifted to other states due to economic reasons. Now the crop is only planted in Imperial County. However, the resting spores of the vector Polymyxa betae with BNYVV can survive in soil for at least 15 years and still transmit the virus (1). So the virus is still ubiquitous in soil of California's agricultural regions. Coinciding with the decline of sugar beet, value of the spinach crop has more than doubled in the last decade as stronger demand has boosted production in the United States, three-fourths of which is in California (29). The rising acreage of spinach as a host of BNYVV may increase the load of the virus in soil. At the high planting density, it would be impossible to separate the diseased from the healthy spinach plants at harvest. A field with even a low disease incidence may have to be plowed under for a total loss, which in turn adds inoculum to the soil. Therefore, BNYVV is a new threat to spinach production in California.

Most sugar beet production areas are dependent upon resistant cultivars to control this devastating disease (4). We found genetic variability in response to BNYVV among a limited number of spinach cultivars, suggesting that genetic improvement of BNYVV resistance through spinach breeding should be feasible. Plant breeding is a long process, often taking more than 10 years. We should start screening spinach genetic resources extensively to identify potential sources of resistance to BNYVV. Resistance found, complete or partial, then can be incorporated into spinach cultivars in a breeding program.

\section{Acknowledgments}

We thank J. Sears, J. Tanaka, R. T. Lewellen, S. Baker, S. Camberos, D. Lara, J. Ochoa, and J. McCreight for technical assistance in the lab and field as well as helpful suggestions, and the California Leafy Greens Research Program for partial funding of the research.

\section{Literature Cited}

1. Abe, H., and Tamada, T. 1986. Association of beet necrotic yellow vein virus with isolates of Polymyxa betae Keskin. Ann. Phytopathol. Soc. Jpn. 52:235-247.

2. Asher, M. J. C. 1993. Rhizomania. Pages 311-346 in: The Sugar Beet Crop, Science in Practice. D. A. Cooke and R. K. Scott, eds. Chapman \& Hall, London.

3. Autonel, C. R., Turina, M., and Fantino, M. G. 1995. Spinach virus infections in Italy [Apulia - Emilia-romagna - Tuscany - Umbria]. Inf. Fitopatol. 45:43-47.

4. Biancardi, E., Lewellen, R. T., DeBiaggi, M., Erichsen, A. W., and Stevanato, P. 2002. The origin of rhizomania resistance in sugar beet. Euphytica 127:383-397.

5. California Beet Growers Association. 1998. The sugarbeet industry in California. http://sugarbeet.ucdavis.edu/sugar_industry.html, accessed July 27, 2011.

6. Canova, A. 1959. Appunti di patologia della barbabietola. Inf. Fitopatol. 20:390-396.

7. Clark, M. F., and Adams, A. N. 1977. Characteristics of the microplate method of enzyme-linked immunosorbent assay for the detection of plant viruses. J. Gen. Virol. 34:475-483.

8. Duffus, J. E., Whitney, E. D., Larsen, R. C., Liu, H.-Y., and Lewellen, R. T. 1984. First report in Western hemisphere of rhizomania of sugar beet caused by Beet necrotic yellow vein virus. Plant Dis. 68:251.

9. Fujisawa, I., and Sugimoto, T. 1976. Transmission of Beet necrotic yellow vein virus by Polymyxa betae. Ann. Phytopathol. Soc. Jpn. 43:583-586.

10. Gidner, S., Lennefors, B.-L., Nilsson, N.-O., Bensefelt, J., Johansson, E., Gyllenspetz, U., and Kraft, T. 2005. QTL mapping of BNYVV resistance from the WB41 source of sugar beet. Genome 48:279-285.

11. Giunchedi, L., and Langeberg, W. G. 1982. Beet necrotic yellow vein virus 
transmission by Polymyxa betae Keskin zoospores. Phytopatol. Mediterr. 21:5-7.

12. Heijbroek, W. 1988. Dissemination of rhizomania by soil, beet seeds and stable manure. Neth. J. Plant Pathol. 94:9-15.

13. Heijbbroek, W., Musters, P. M. S., and Schoone, A. H. L. 1999. Variation in pathogenicity and multiplication of Beet necrotic yellow vein virus (BNYVV) in relation to the resistance of sugar beet cultivars. Eur. J. Plant Pathol. 105:397-405.

14. Koike, S. T., Henderson, D. M., and Butler, E. E. 2001. Leaf spot disease of spinach in California caused by Stemphylium botryosum. Plant Dis. 85:126130

15. Lewellen, R. T. 1997. Registration of 11 sugarbeet germplasm lines with resistance to rhizomania. Crop Sci. 37:1026.

16. Lewellen, R. T., Skoyen, I. O., and Erichsen, A. W. 1987. Breeding sugarbeet for resistance to rhizomania: Evaluation of host-plant reactions and selection for and inheritance of resistance. Pages 139-156 in: Proc. 50th Winter Congress IIRB. International Institute for Beet Research, Brussels.

17. Liu, H.-Y., and Lewellen, R. T. 2007. Distribution and molecular characterization of resistance-breaking isolates of Beet necrotic yellow vein virus in the United States. Plant Dis. 91:847-851.

18. Liu, H.-Y., Mou, B., Richardson, K., and Koike, S. T. 2010. First report of Beet necrotic yellow vein virus infecting spinach in California. Plant Dis. 94:640.

19. Liu, H.-Y., Sears, J. L., and Lewellen, R. T. 2005. Occurrence of resistancebreaking Beet necrotic yellow vein virus of sugar beet. Plant Dis. 89:464468

20. Rush, C. M. 2009. Beet necrotic yellow vein virus. Pages $42-44$ in: Compendium of Beet Diseases and Pests, 2nd ed. R. Harveson, L. Hanson, and
G. Hein, eds. American Phytopathological Society, St. Paul, MN

21. Rush, C. M., Liu, H.-Y., Lewellen, R. T., and Acosta-Leal, R. 2006. The continuing saga of rhizomania of sugar beet in the United States. Plant Dis 90:4-15.

22. Rysanek, P., Homa, I., and Zouhar, M. 2006. Study of sugar beet viruses transmitted by Polymyxa betae in the Czech Republic. Pages 47-54 in: Proc. Int. Sympos. Sugar Beet Prot., Novi Sad (Serbia and Montenegro), Sept 26-28, 2005.

23. Scholten, O. E., DeBock, T. S. M., Kleinlankhorst, R. M., and Lange, W. 1999. Inheritance of resistance to Beet necrotic yellow vein virus in Beto vulgaris conferred by a second gene for resistance. Theor. Appl. Genet. 99:740-746.

24. Scholten, O. E., Jansen, R. C., Keiser, L. C. P., DeBock, T. S. M., and Lange, W. 1996. Major genes for resistance to Beet necrotic yellow vein virus (BNYVV) in Beta vulgaris. Euphytica 91:331-339.

25. Scholten, O. E., Paul, D., van Lent, J. W. M., and Goldbach, R. W. 1994. In Situ localization of beet necrotic yellow vein virus (BNYVV) in rootlets of susceptible and resistant beet plants. Arch. Virol. 136:349-361.

26. Tamada, T. 1975. Beet necrotic yellow vein virus. CMI/AAB Description of Plant Viruses. No. 144

27. Tamada, T. 1999. Benyviruses. Pages $154-160$ in: Encyclopedia of Virology, 2nd ed. Vol. II. A. Granoff and R. Webster, eds. Academic Press, London.

28. Tamada, T., Uchino, H., Kusume, T., and Saito, M. 1999. RNA 3 deletion mutants of beet necrotic yellow vein virus do not cause rhizomania disease in sugar beets. Phytopathology 89:1000-1006.

29. U.S. Dep. Agric., Economic Research Service (ERS). 2007. Fresh-market spinach: Background information and statistics. http://www.ers.usda.gov/ News/spinachcoverage.htm, accessed July 27, 2011. 